\title{
Alkollü İçecek Vergilerinin Sosyal Maliyetleri Azaltıcı Etkilerinin Bireysel Tutumlar Yönünden Analizi (İstanbul İli Örneği)
}

Ufuk GERGERLIOG $\breve{G} \boldsymbol{U}$, Department of International Business and Trade, Faculty of Commerce, Yeditepe University, Turkey; e-mail: ufukyunus@gmail.com

Kutluk Kă̆an SÜMER, Department of Econometrics, Faculty of Economics, Istanbul University, Turkey; email: kutluk@istanbul.edu.tr

\section{Analysing of Mitigating Effects of Spirits Sale Taxes on Social Costs in terms of Individual Attitudes (Istanbul Province Case) ${ }^{2}$}

\begin{abstract}
In this article, in terms of education, income and marital status variable from the perspective of the Turkey the social costs mitigating effects of spirits sale taxes which imposed on the individual attitudes will be analyzed.

Keywords : Spirits Sale Tax, Attitude, Social Cost.

JEL Classification Codes : $\mathrm{H} 20, \mathrm{H} 30$.

\section{Öz}

$\mathrm{Bu}$ makalede, Türkiye perspektifinde alkollü içecekler üzerine salınan özel tüketim vergilerinin sosyal maliyetleri azaltıcı etkilerinin bireysel tutumlar yönünden analizi yapılacak ve ortaya çıkan sonuçlar eğitim, gelir ve medeni hal değişkenleri göz önünde bulundurularak değerlendirilecektir.

Anahtar Sözcükler : Alkollü İçecekler Vergisi, Tutum, Sosyal Maliyet.

1 Bu makale, "Davranışları Etkilemeye Yönelik Özel Tüketim Vergilerinin Tutum ve Davranışlar Üzerindeki Etkilerinin Ampirik Analizi (İstanbul İli Örneği)" adlı doktora tez çalışmasından üretilmiştir.

2 This article has been generated from the dissertation which is titled as "Analysing of Mitigating Effects of Spirits Sale Taxes on Social Costs in terms of Individual Attitudes (Istanbul Province Case)”.
\end{abstract}




\section{Giriş}

Vergilerin bireylerin tutum ve davranışlarını etkilediği bilinmektedir. Ancak vergilerin bu etkisi, demografik nitelikteki faktörlerin varlığında ve başkaca unsurların mevcudiyetinde bir takım farklılıklar ortaya koymaktadır. Bu durumu destekleyen birçok ampirik çalışma mevcuttur. Aynı zamanda birçok ampirik çalışma, vergilerin bir taraftan sosyal maliyetleri azaltıcı etkiler oluşturduğunu ve diğer taraftan da vergilemeye yönelik bir takım olumsuz tutumsal eğilimler açığa çıkarttığını göstermektedir. Elbette bu sonuçlar, vergilerin yapılarına göre farklılık arz etmektedir. Özellikle dolaysız vergiler ile dolaylı vergiler ayrımında, dolaylı vergilerin kendilerine has bir takım özelliklerinden ötürü dolaysız vergilere kıyasla daha az tutumsal tepkiye neden oldukları gözlenmektedir. Bilhassa bu tepki, dolaylı vergi kapsamında yer alan özel tüketim vergilerinde daha net bir biçimde ortaya çıkmaktadır.

Bu kapsamda bu çalışmada, alkollü içecek vergilerinin sosyal maliyeti azaltıcı etkileri eğitim, medeni hal ve gelir bağımsız değişkenine göre analiz edilerek değerlendirilecektir. Bu bağlamda öncelikle alkollü içecek vergilerine yönelik olarak sosyal maliyetler ve bireysel tutumlar ekseninde yapılan mevcut ampirik çalışma sonuçları ele alınacaktır. Ardından alkollü içeceklere yönelik özel tüketim vergileri kapsamında yapılan saha araştırma sonuçları, eğitim, medeni hal ve gelir bağımsız değişkeni çerçevesinde analiz edilerek değerlendirilecektir.

\section{Alkollü İçecek Vergilerine Yönelik Olarak Sosyal Maliyetler ve Bireysel Tutumlar Ekseninde Yapılan Mevcut Ampirik Çalışma Sonuçlarının Değerlendirilmesi}

Maliye literatüründe alkollü içeceklerin vergilendirilmesine yönelik olarak yapılmış birçok saha araştırması mevcuttur. Bu saha çalışmaları genellikle alkollü içecek vergilerinin sosyal maliyetler kapsamında değerlendirilmesini içermektedir. Bununla birlikte alkollü içecek vergilemesinin bireylerin tutumları üzerinde nasıl bir etki oluşturduğuyla ilgili de birçok çalışma yapılmıştır. Bu araştırmalara yönelik sonuçlardan bahsetmeden önce maliye literatürü çerçevesinde alkollü içeceklerin vergilendirilmesinin etkilerine ilişkin kısa bir değerlendirme yapmak anlamlı olacaktır.

Alkollü içecek tüketimi, hem bireysel yönden içki kullanan kişiler için özel maliyet oluşturmakta hem de toplumsal yönden birtakım sosyal maliyetler meydana getirebilmektedir. Böyle bir durum da toplumsal maliyetlerin içselleştirilmesi gerektiğini ortaya çıkartmaktadır (Smith, 2005: 67-68). İşte bu noktada vergilerin bir araç olarak kullanılması gündeme gelmektedir (Heien, 1995: 243). Ancak toplumsal maliyetlerin içselleştirilmesi adına salınan alkollü içecek vergileri bazı problemleri de beraberinde getirmektedir. 
Bu problemlerden birisi alkollü içecekler üzerine salınan vergilerin gelir düzeyi gözetilmeksizin uygulanmasıyla ilgilidir (Sexton, 2013: 242). Bundan dolayı bu nitelikteki vergiler gerileyici özellik ortaya koymakta ve marjinal tüketim eğilimi yüksek insanların üzerinde bir yük oluşturmaktadır (Lorenzi, 2004: 59). Dolayısıyla bu nitelikteki vergilerin tüketim kararlarını etkilediği kabul edilmektedir (Badenes-Plá and Jones, 2003: 127).

$\mathrm{Bu}$ bağlamda yapılan birçok ampirik araştırma literatürdeki bu açıklamaları doğrular niteliktedir. Gabe (2008) alkollü içeceklere yönelik özel tüketim vergilerinin tüketici talepleri üzerinde azaltıcı bir etki ortaya koyduğunu göstermiştir.

Aynı zamanda bazı saha araştırması sonuçları alkollü içki vergilemesinin alkollü içki tüketiminin meydana getirdiği toplumsal maliyetleri içselleştirdiğini de ortaya koymaktadır. Son ve Topyan (2011), şarap gibi alkol derecesi nispeten düşük içkiler üzerindeki vergi artışlarının alkol tüketimine bağlı ölümcül hastalık riskini azaltacağını açığa çıkartmıştır. Bu sonuca ilave olarak Durrance vd. (2011), yaptıkları bir araştırmada alkollü içecek tüketimi artışının kadın cinayetlerini çoğalttığını ve bu durumun alkollü içecek vergileri yoluyla azaltılabileceğini tahmin etmişlerdir. Alkollü içki vergilemesinin sosyal maliyetleri azaltıcı bu etkilerinin yanında bireylerin tutumları üzerinde de yönlendirici bir etki oluşturdukları bilinmektedir.

Bu bağlamda Nordblom (2006) tarafından yapılan 1692 kişinin katılımıyla yapılan bir çalışma, alkol içki tüketimi üzerine uygulanan vergilerin bireylerin tutumları üzerinde ne yönde bir etki oluşturduğunu ortaya koymaktadır. Bu çalışmaya yönelik sonuçlar şu şekildedir:

- Örnek kitlenin \%20'si alkol vergilerinin kaldırılmasından veya oldukça fazla miktarda azaltılmasından yana tutum ortaya koymuşlardır.

- $\quad$ Örnek kitlenin \%35’i alkol vergilerinin az bir miktar düşürülmesi yönünde tutum sergilemişlerdir.

- Örnek kitlenin \%25'i alkol vergilerinin değiştirilmemesinden yana bir tutumsal eğilim gösterirken aynı örnek kitlenin \%6'sı az bir miktarda artış olabileceğinden yana bir tutum ortaya koymuşlardır.

- Örnek kitlenin \%7'si alkol vergilerinin çok fazla arttırılması gerektiğini düşünürken aynı örnek kitlenin \%7'si alkol vergileri ile alakalı olarak kararsız bir tutum sergilemişlerdir.

Tüm bu sonuçlar bir arada değerlendirildiğinde, özel tüketim vergilerinin sosyal veya toplumsal maliyetleri azaltıcı etkiler oluşturduğu ve aynı zamanda bu nitelikteki vergilerin bireylerin tutumsal eğilimlerini olumsuz yönde etkilediği görülmektedir. İște bu noktada bireylerin özel tüketim vergilerinin sosyal maliyetleri azaltıcı etkilerini ne ölçüde desteklediği önem kazanmaktadır. Bu bağlamda bu çalışmada ciddi dışsal maliyetler 
oluşturan ve özel tüketim vergileri kapsamında değerlendirilen alkollü içeceklerin vergileme ve demografik unsurlar çerçevesinde değerlendirilmesine yer verilecektir.

\section{Alkollü İçeceklere Yönelik Özel Tüketim Vergileri Kapsamında Yapılan Saha Araştırma Sonuçlarının Eğitim, Gelir ve Medeni Hal Değişkeni Çerçevesinde Analiz Edilerek Değerlendirilmesi}

$\mathrm{Bu}$ ana başlık altında, davranışları etkilemeye yönelik özel tüketim vergilerinin sosyal maliyetleri azaltıcı etkilerinin analizi ve bu analize yönelik sonuçların değerlendirilmesi, temel demografik nitelikteki değişkenler perspektifinden yapılacaktır. Bu bağlamda bu çalışma, iki kısımdan oluşmaktadır. İlk olarak, doktora tezi çerçevesinde yapılan saha araştırmasının genel hususlarına değinilecektir. Sonrasında, bireylerin davranışlarını etkilemeye yönelik özel tüketim vergilerinin sosyal maliyeti azaltıcı etkilerinin analizi ve değerlendirmesi, bağımsız eğitim, medeni hal ve gelir değişkeni ekseninde yapılacaktır.

\subsection{Araştırmanın Genel Çerçevesi}

Bu başlık altında ilk olarak bu çalışmanın hangi amaç için yapıldığı konusuna değinilecektir. Ardından bu çalışma bağlamında belirlenen ana kitle ve örnek kitle verilerine ilişkin değerlendirmelerde bulunulacaktır. Daha sonra araştırmanın yönteminin ne olduğuna yönelik bir açıklama yapılarak kullanılan istatistiki metotlardan bahsedilecektir. Son olarak örnekleme ile alakalı bilgilere yer verilecektir.

\subsection{1. Çalışmanın Amacı}

$\mathrm{Bu}$ çalışmada, davranışları etkilemeye yönelik özel tüketim vergileri kapsamındaki alkollü içecek vergilerinin sosyal maliyetleri azaltıcı etkisinin bireylerin tutumları üzerinde nasıl bir etki oluşturduğunun analizi yapılacaktır. $\mathrm{Bu}$ bağlamda İstanbul'da yaşayan bireylerin tutumları eğitim, gelir ve medeni hal bağımsız değişkeni ekseninde test edilmektedir.

\subsubsection{Ana Kitle ve Örnek Kitle Verilerine İlişkin Değerlendirme}

Literatürde, ana kitle, tüm birimlerden oluşan küme biçiminde ifade edilirken örnek kitle ana kitlenin bir alt kümesi şeklinde tanımlanmaktadır (Güler, 2008: 4). Literatürdeki bu açıklama çerçevesinde yapılan saha çalışması için ana kitle, İstanbul'da yaşayan 20 yaş ve üstü bireyler olarak tanımlanmıştır. Bu kapsamda araştırmanın ana kitlesi, TÜİK'in adrese dayalı nüfus sayımına bağlı kalınarak tespit edilmiştir. Bu durumda ana kitle, 31 Aralık 2012 için 9.564.693 kişiden oluşmaktadır. Ancak, Şile, Çatalca ve Adalar ilçeleri, örneklem sayısının yetersizliğinden dolayı rassal örneklem tablosuna dâhil 
edilmemiştir. $\mathrm{Bu}$ ana kitlenin alt kümesini oluşturan örnek kitle, İstanbul ili sınırları içerisindeki 1000 kişiden oluşmaktadır. Bu örnek kitle ilçe, yaş ve cinsiyet verilerine bağlı kalınarak tabakalı rassal örnekleme esasına göre seçilmiştir.

1000 kişilik örnek kitle, $n=\mathrm{Nt}^{2} \mathrm{pq} /\left(\mathrm{d}^{2}(\mathrm{~N}-1)+\mathrm{t}^{2} \mathrm{pq}\right.$ formülüne bağlı kalınarak tespit edilmiştir. $\mathrm{Bu}$ formül ana kitlenin bilindiği durumlarda kullanılmaktadır. Formüle göre, $\mathrm{n}$ örnek kitleyi, $\mathrm{N}$ ana kitleyi, d örneklem hatasını, t belirli bir anlamlılık düzeyinde $\mathrm{t}$ tablosuna göre bulunun değeri, $\mathrm{p}$ ve $\mathrm{q}$ da verilerin homojen olup olmadığını ortaya koyan katsayıları ifade etmektedir. Bu bağlamda bu formüle $\mathrm{N}=9.564 .693$ kişi, $\mathrm{t}=1,96(\% 95$ güvenilirlik aralığında $\mathrm{t}$ tablosuna karşılık gelen değer), $\mathrm{d}=\%$ 3-\%4 aralığında örneklem hatası, $\mathrm{p}=0.5$ ile $\mathrm{q}=0.5$ (verilerin homojen olmadığından hareketle belirlenen değerler) sayısal değerleri uygulandığında 1000 kişilik örnek kitleye ulaşılmaktadır. İlçe, cinsiyet ve yaş verileri ile alakalı tabakalı rassal örnekleme tablosu, Tablo: 1'de görülmektedir.

Tablo: 1

\section{İlçe, Cinsiyet ve Yaş Verilerine Göre Tabakalı Rassal Örnekleme Tablosu}

\begin{tabular}{|c|c|c|c|c|c|c|c|c|c|}
\hline \multirow{2}{*}{ İLÇE } & \multirow{2}{*}{$\begin{array}{c}20-24 \\
\text { Yaş Aralığı }\end{array}$} & \multirow{2}{*}{$\begin{array}{c}25-39 \\
\text { Yaş Aralığı }\end{array}$} & \multirow{2}{*}{$\begin{array}{c}40-59 \\
\text { Yaş Aralığ }\end{array}$} & \multirow{2}{*}{$\begin{array}{c}60+ \\
60 \text { ve Üstü Yaş Grubu }\end{array}$} & \multirow{2}{*}{ TOPLAM } & \multicolumn{2}{|c|}{ TOPLAM } & \multirow{2}{*}{ İlçe Yüzde } & \multirow{2}{*}{ İlçe toplam } \\
\hline & & & & & & Kadın & Erkek & & \\
\hline Arnavutköy & 16.731 & 56.721 & 38.143 & 11.606 & 123.201 & \begin{tabular}{|l|}
6 \\
\end{tabular} & 6 & $1 \%$ & 13 \\
\hline Ataşehir & 30.871 & 116.169 & 98.228 & 34.134 & 279.402 & 15 & 15 & $3 \%$ & 29 \\
\hline Avcılar & 32.707 & 117.463 & 92.808 & 31.339 & 274.317 & 14 & 14 & $3 \%$ & 29 \\
\hline Bağcılar & 61.765 & 218.554 & 152.803 & 40.326 & 473.448 & 25 & 25 & $5 \%$ & 50 \\
\hline Bahçelievler & 48.445 & 176.521 & 143.751 & 50.833 & 419.550 & 22 & 22 & $4 \%$ & 44 \\
\hline Bakırköy & 16.315 & 55.931 & 65.064 & 40.188 & 177.498 & 9 & 9 & $2 \%$ & 19 \\
\hline Başakşehir & 22.598 & 91.340 & 65.286 & 14.226 & 193.450 & 10 & 10 & $2 \%$ & 20 \\
\hline Bayrampaşa & 21.292 & 74.676 & 69.326 & 25.641 & 190.935 & 10 & 10 & $2 \%$ & 20 \\
\hline Beşiktaş & 15.369 & 52.271 & 51.522 & 34.972 & 154.134 & 8 & 8 & $2 \%$ & 16 \\
\hline \begin{tabular}{|l|} 
Beykoz \\
\end{tabular} & 20.046 & 65.945 & 64.897 & 24.873 & 175.761 & 9 & 9 & $2 \%$ & 19 \\
\hline Beylikdüzü & 15.059 & 67.890 & 57.892 & 19.259 & 160.100 & 8 & 8 & $2 \%$ & 17 \\
\hline \begin{tabular}{|l|} 
Beyoğlu \\
\end{tabular} & 20.455 & 70.028 & 61.836 & 23.046 & 175.365 & 9 & 9 & $2 \%$ & 18 \\
\hline Büyükçekmece & 14.437 & 55.506 & 50.219 & 19.578 & 139.740 & 7 & 7 & $1 \%$ & 15 \\
\hline Çekmeköy & 15.080 & 58.735 & 42.576 & 11.164 & 127.555 & 7 & 7 & $1 \%$ & 13 \\
\hline Esenler & 37.747 & 131.369 & 95.853 & 24.705 & 289.674 & 15 & 15 & $3 \%$ & 31 \\
\hline Esenyurt & 46.572 & 174.539 & 101.636 & 25.002 & 347.749 & 18 & 18 & $4 \%$ & 37 \\
\hline Eyüp & 28.380 & 102.388 & 88.319 & 30.447 & 249.534 & 13 & 13 & $3 \%$ & 26 \\
\hline Fatih & 37.855 & 112.630 & 107.899 & 58.467 & 316.851 & 17 & 17 & $3 \%$ & 33 \\
\hline Gaziosmanpaşa & 37.870 & 138.058 & 112.987 & 36.838 & 325.753 & 17 & 17 & $3 \%$ & 34 \\
\hline \begin{tabular}{|l|} 
Güngören \\
\end{tabular} & 25.840 & 86.464 & 75.589 & 28.416 & 216.309 & 11 & 11 & $2 \%$ & 23 \\
\hline Kadıköy & 33.264 & 132.702 & 148.267 & 116.695 & 430.928 & 23 & 23 & $5 \%$ & 45 \\
\hline Kâğıthane & 33.988 & 125.356 & 101.697 & 30.199 & 291.240 & 15 & 15 & $3 \%$ & 31 \\
\hline Kartal & 32.591 & 127.510 & 114.073 & 43.405 & 317.579 & 17 & 17 & $3 \%$ & 33 \\
\hline Küçükçekmece & 57.098 & 212.548 & 165.097 & 53.120 & 487.863 & 26 & 26 & $5 \%$ & 51 \\
\hline Maltepe & 35.585 & 133.335 & 121.356 & 53.734 & 344.010 & 18 & 18 & $4 \%$ & 36 \\
\hline Pendik & 47.178 & 187.715 & 139.847 & 43.083 & 417.823 & 22 & 22 & $4 \%$ & 44 \\
\hline Sancaktepe & 22.588 & 84.079 & 54.842 & 13.619 & 175.128 & 9 & 9 & $2 \%$ & 18 \\
\hline Sariyer & 27.216 & 78.222 & 76.696 & 31.469 & 213.603 & 11 & 11 & $2 \%$ & 23 \\
\hline Silivri & 12.235 & 43.303 & 37.276 & 16.005 & 108.819 & 6 & 6 & $1 \%$ & 11 \\
\hline Sultanbeyli & 26.574 & 82.470 & 53.774 & 12.723 & 175.541 & 9 & 9 & $2 \%$ & 19 \\
\hline Sultangazi & 39.525 & 143.747 & 94.830 & 24.207 & 302.309 & 16 & 16 & $3 \%$ & 32 \\
\hline Şiş̧i & 25.483 & 97.083 & 81.665 & 40.156 & 244.387 & 13 & 13 & $3 \%$ & 26 \\
\hline Tuzla & 18.147 & 57.243 & 43.959 & 12.754 & 132.103 & 7 & 7 & $1 \%$ & 14 \\
\hline Ümraniye & 48.264 & 197.973 & 149.907 & 41.982 & 438.126 & 23 & 23 & $5 \%$ & 46 \\
\hline \begin{tabular}{|l|} 
Üsküdar \\
\end{tabular} & 44.611 & 147.540 & 140.385 & 62.500 & 395.036 & 21 & 21 & $4 \%$ & 42 \\
\hline Zeytinburnu & 24.628 & 81.790 & 69.065 & 22.880 & 198.363 & 10 & 10 & $2 \%$ & 21 \\
\hline TOPLAM & 1.094 .409 & 3.955 .814 & 3.229 .370 & 1.203 .591 & 9.483 .184 & 500 & 500 & $100 \%$ & 1000 \\
\hline
\end{tabular}


Tabakalı rassal örneklem yöntemine göre seçilen 1000 örneklemin kadın ve erkek için eşit olduğu Tablo: 1'de görülmektedir. Bu durumun kanıtı, 31 Aralık 2012 tarihi itibarıyla 13.854.740 kişiden oluşan İstanbul nüfusunun \%50.2'sinin (6.956.908 kişi) erkeklerden ve \%49.8'inin (6.897.832 kişi) ise kadınlardan oluşmasıdır. Aynı zamanda Tablo: 1, İstanbul ilçe nüfuslarını çalışmanın örnek kitlesini göz önünde bulundurarak ilçelere göre oranlı bir biçimde dağıtmıştır. Bununla birlikte Tablo: 1, her ilçe için yaş gruplarına göre de ayırım yapmıştır.

\subsubsection{Araştırmanın Yöntemi ve Kullanılan İstatistiki Metotlar}

Doktora tezi kapsamında yapılan saha araştırma çalışması, 2013 Aralık ayı içinde İstanbul'daki 36 ilçeyi kapsamaktadır. Bu çalışma, tecrübeli anketör tarafından yüz yüze anket yöntemi ile yapılmıştır. Yaklaşık 1100 kişi ile anket yapılmış, ancak 1018 kişinin anketi uygun görülmüştür. Bu kapsamda analiz çalışmaları, 1018 kişinin verilerine bağlı kalınarak yapılmıştır. 1018 kişinin verilerine bağlı kalınması, daha önce belirlenen örnek kitle (1000) açısından istatistiksel manada bir sıkıntı oluşturmamaktadır.

Doktora çalışmasının anket bölümü, altı kısımdan oluşmaktadır. Ancak bu makalede, sadece alkollü içecekler vergilerinin sosyal maliyetleri azaltıcı etkilerine yönelik bireysel tutumlar dikkate alınacak ve bu tutumlar eğitim, gelir ve medeni hal değişkeni çerçevesinde açıklanacaktır.

Anket formları, Sosyal Bilimler Tabanlı İstatistik Paketi (Statistical Package for Social Science SPSS 21) kullanılarak analiz edilmiştir. 59 tutum ifadesi için Cronbach's Alfa Güvenilirlik değeri 0.895 olarak belirlenmiştir.

$\mathrm{Bu}$ çalışmada, öncelikle, alkollü içecek vergilerinin sosyal maliyeti azaltıcı etkilerinin bireysel tutumlar ekseninde nasıl bir sonuç ortaya koyduğu sıklık (frekans) analizleri yardımıyla açıklanmıştır. Sonrasında aynı tutum ifadeleri için parametrik olmayan Kruskal -Wallis $\mathrm{H}$ istatistiksel test sonuçlarına yer verilmiştir. Aynı zamanda her teste ilişkin hipotezler EK: 1'de gösterilen tablo altlıklarında gösterilmiştir.

\subsection{4. Örnekleme Yönelik Bilgiler}

Bu kapsamda bu saha araştırması için örnekleme ilişkin güvenilirlik düzeyi $\% 95$ olarak belirlenmiş, örnekleme hatası ise $\% 3$ olarak tanımlanmıştır. Ankete katılım sağlayan 1018 kişi ile alakalı temel veriler, sıklık (frekans) tabloları aracılığıyla aşağıda belirtilmiştir.

Ankete katılanların cinsiyet dağı̆lımı, Tablo: 2'de gösterilmiştir. 
Tablo: 2

Katılımcıların Cinsiyet Durumu Gösteren Sıklık Tablosu

\begin{tabular}{|c|r|r|r|}
\hline & \multicolumn{2}{|c|}{ S1klık } & \multicolumn{2}{|c|}{ Yüzde } & Geçerli Yüzde \\
\hline Kadın & 502 & 49,3 & 49,3 \\
\hline Erkek & 516 & 50,7 & 50,7 \\
\hline Toplam & 1018 & 100,0 & 100,0 \\
\hline
\end{tabular}

Ankete katılanların eğitim durumu, Tablo: 3'te belirtilmiştir. Tablo: 3, ankete en çok katılanların ilkokul (\%30.6) ve lise mezunları (\%33.3) olduğunu göstermiştir.

Tablo: 3

Katılımcıların Eğitim Durumu Gösteren Sıklık Tablosu

\begin{tabular}{|l|r|r|r|}
\hline & \multicolumn{1}{|c|}{ Sıklık } & \multicolumn{1}{|c|}{ Yüzde } & Geçerli Yüzde \\
\hline Mezun Değil & 33 & 3,2 & 3,2 \\
\hline İlkokul Mezunu & 312 & 30,6 & 30,6 \\
\hline Ortaokul Mezunu & 146 & 14,3 & 14,3 \\
\hline Lise Mezunu & 339 & 33,3 & 33,3 \\
\hline Üniversite Mezunu & 162 & 15,9 & 15,9 \\
\hline Lisansüstü Mezunu & 26 & 2,6 & 2,6 \\
\hline TOPLAM & 1018 & 100,0 & 100,0 \\
\hline
\end{tabular}

Katılımcıların medeni durumuna ilişkin veriler Tablo: 4’te belirtilmiştir. Tablo: 4 , ankete en çok katılanların evliler $(\% 63,1)$ olduğunu göstermiştir.

Tablo: 4

\section{Katılımcıların Medeni Hal Durumu Gösteren Sıklık Tablosu}

\begin{tabular}{|c|c|c|c|}
\hline & Siklık & Yüzde & Geçerli Yüzde \\
\hline Evli & 642 & 63,1 & 63,1 \\
\hline Bekâr & 323 & 31,7 & 31,7 \\
\hline Dul & 53 & 5,2 & 5,2 \\
\hline Toplam & 1018 & 100,0 & 100,0 \\
\hline
\end{tabular}

Tablo: 5'te, katılımcıların gelir düzeyi gösterilmektedir. Ankete en çok katılanların 1001-2000 TL arası gelire sahip olanlardan (\%34.1) meydana geldiği, Tablo: 5'ten anlaşılmaktadır. 
Tablo: 5

Katılımcıların Gelir Düzeyi Gösteren Sıklık Tablosu

\begin{tabular}{|c|r|r|r|}
\hline & Sıklık & Yüzde & Geçerli Yüzde \\
\hline Hiç Geliri Olmayanlar & 291 & 28,6 & 28,6 \\
\hline 773 TL'den Az Gelire Sahip Olanlar & 31 & 3,0 & 3,0 \\
\hline $773-1.000$ TL Arası Gelire Sahip Olanlar & 148 & 14,5 & 14,5 \\
\hline $1.001-2.000$ TL Arası Gelire Sahip Olanlar & 347 & 34,1 & 34,1 \\
\hline $2.001-4.000$ TL Arası Gelire Sahip Olanlar & 158 & 15,5 & 15,5 \\
\hline $4.001-6.000$ TL Arası Gelire Sahip Olanlar & 29 & 2,8 & 2,8 \\
\hline 6.001 TL'den Fazla Gelire Sahip Olanlar & 14 & 1,4 & 1,4 \\
\hline TOPLAM & 1018 & 100,0 & 100,0 \\
\hline
\end{tabular}

\section{Alkollü İçeceklere Salınan Vergilerin Sosyal Maliyetleri Azaltııı Etkilerine Yönelik Bilişsel Tutumlara İliş̧in Analiz Sonuçlarının Bir Arada Ele Alınması}

Alkollü içeceklere salınan vergilerin sosyal maliyetleri azaltıcı etkilerine yönelik bilişsel tutumların bir arada değerlendirilmesinde beş ayrı tablodan yararlanılacaktır. $\mathrm{Bu}$ tablolardan ilki, alkollü içecek vergilerinin sosyal maliyetleri azaltması ile alakalı beş farklı bilişsel tutum için sıklık analizi sonuçlarını bir arada değerlendirmektedir. İkinci tablo, alkollü içecek vergilerinin sosyal maliyetleri azaltması ile alakalı beş farklı bilişsel tutumun bağımsız gelir değişkeni ile nasıl bir etkileşim içerisinde olduğunu ortaya koymaktadır. Üçüncü tablo, alkollü içecek vergilerinin sosyal maliyetleri azaltması ile ilgili beş ayrı bilişsel tutumun medeni hal bağımsız değişkeni ile nasıl bir görünüm ortaya koyduğunu anlatmaktadır. Son tablo ise, alkollü içecek vergilerinin sosyal maliyetleri azaltmasına yönelik beş bilişsel tutum ifadesi ile eğitim bağımsız değişkeni arasındaki ilişkiyi açığa çıkartmaktadır.

Tablo: 6'da, alkollü içeceklerin üzerine salınan vergilerin nasıl bir tutumsal eğilim açığa çıkarttığıyla ilgili bilişsel tutum ifadeleri yer almaktadır. Bu tutum ifadeleri, alkol tüketimi ile ortaya çıkan sosyal maliyetlerin azaltılmasına yönelik bir nitelik taşımaktadır. Bu bilgiler ışığında Tablo: 6, ilgili tutumlara ilişkin sıklık analizi sonuçlarını ortaya koymaktadır (Ek:1). Bu sıklık analizi sonuçları bir arada değerlendirildiğinde ise şu sonuçların ortaya çıktığı görülmektedir:

- Örnek kitlenin \%60.9’u, alkollü içeceklerden alınan vergilerin özel bir fonda toplanması ve bu fonların alkol kullanımına ilişkin hastalıkların iyileştirilmesinde kullanılması şartıyla yüksek vergi artışlarını desteklemektedir. Bu tutuma yönelik destekleme, benzer nitelikteki diğer tutumlara nazaran daha yüksek bir görünümdedir. Buna karşın bu tutum ile alakalı kararsızlık eğilimi, diğer tutumsal ifadelere kıyasla daha fazladır. 
- $\quad$ Bu tutum grubu içerisinde en düşük kararsızlık eğilimi, "alkollü içeceklerin tüketimi üzerine konulan yüksek vergilerin hastalık riskini azaltacağına inanıyorum" bilişsel tutum ifadesinde ortaya çıkmaktadır.

- $\quad$ Alkollü içeceklere salınan yüksek oranlı vergilerin şiddet ve intihar olaylarını azaltacağına inanmayanlar, bu tutuma inananlardan daha yüksek düzeyde bir eğilim ortaya koymaktadırlar.

- $\quad$ Örnek kitlenin neredeyse yarısı, alkollü içecek tüketiminin, alkole ilişkin hastalık riskinin ve aşırı alkol tüketimi ile oluşan sosyal maliyetlerin yüksek vergilerle azalacağını kabul etmektedir.

Tablo: 6

Alkollü İçeceklere Salınan Vergilerin Sosyal Maliyeti Azaltıcı Etkilerine Yönelik Bilişsel Tutumlara İlişkin Sıklık Analizlerinin Bir Arada Değerlendirilmesi

\begin{tabular}{|c|c|c|c|c|}
\hline BİLISSSEL TUTUMLAR & $\begin{array}{l}\text { İlgili Tutumu } \\
\text { Destekleme } \\
\text { Oranı }\end{array}$ & $\begin{array}{l}\text { İlgili Tutuma } \\
\text { Katılmama } \\
\text { Oranı }\end{array}$ & $\begin{array}{l}\text { İlgili Tutum } \\
\text { İçin } \\
\text { Kararsızlık } \\
\text { Oranı } \\
\end{array}$ & Toplam \\
\hline $\begin{array}{l}\text { Eğer Alkollü İceceklerden Alınan Vergiler, Özel } \\
\text { Bir Hesapta Toplanıp Alkol Kullanımına İlişkin } \\
\text { Hastalıkların İyileștirilmesinde Kullanılacaksa } \\
\text { Yüksek Vergi Artışlarını Kabul Edebilirim }\end{array}$ & $\% 60.9$ & $\% 25.3$ & $\% 13.9$ & $\% 100.0$ \\
\hline $\begin{array}{l}\text { Alkollü İçeceklerin Tüketimi Üzerine Konulan } \\
\text { Yüksek Vergilerin Hastalık Riskini Azaltacağına } \\
\text { İnanıyorum. }\end{array}$ & $\% 50.2$ & $\% 43.6$ & $\% 6.2$ & $\% 100.0$ \\
\hline $\begin{array}{l}\text { Alkollü İçecek Tüketiminin Yüksek Vergilerle } \\
\text { Azalacağını Düşünüyorum }\end{array}$ & $\% 49.8$ & $\% 42.0$ & $\% 8.2$ & $\% 100.0$ \\
\hline $\begin{array}{l}\text { Aşırı Alkol Tüketimi Topluma Önemli Maliyetler } \\
\text { Yüklediği İçin Yüksek Oranlı Alkol Vergilerini } \\
\text { Destekliyorum }\end{array}$ & $\% 49.3$ & $\% 39.5$ & $\% 11.2$ & $\% 100.0$ \\
\hline $\begin{array}{l}\text { Alkollü İçeceklere Yüklenilen Yüksek Oranlı } \\
\text { Vergilerin Şiddet Ve İntihar Olaylarını } \\
\text { Azaltacağına İnanıyorum }\end{array}$ & $\% 43.5$ & $\% 45.5$ & $\% 11.0$ & $\% 100.0$ \\
\hline
\end{tabular}

Tablo: 7, alkollü içeceklerin üzerine salınan vergilerin gelir bağımsız değişkeni göz önünde bulundurularak nasıl bir tutumsal eğilime sebebiyet verdiğini göstermektedir. Tablo: 7 'deki veriler, Kruskal-Wallis U testi sonuçlarından elde edilen sıra ortalamalarını ifade etmektedir. İlgili tutuma ilişkin sıra ortalama rakamları, gelir seviyesine göre değişebilen ve tutumların birbiriyle mukayesesine izin veren bir gösterge niteliğindedir. Dolayısıyla daha yüksek sıra ortalaması rakamı, daha güçlü tutumu açığa çıkartmakta veya tam tersi daha düşük sıra ortalaması rakamı, daha zayıf tutumu ortaya koymaktadır.

$\mathrm{Bu}$ tutum ifadeleri, alkol tüketimi ile ortaya çıkan sosyal maliyetlerin azaltılmasına yönelik bir özellik taşımaktadır. Bu bağlamda Tablo: 7, ilgili tutumlara ilişkin sıra ortalaması sonuçlarını farklı gelir düzeylerine göre değerlendirmektedir. Ayrıca Tablo: 
7'deki tüm verilerin Kruskal-Wallis P değerleri, istatistiksel açıdan anlamlılık içermektedir (Ek: 1). Bu test analizleri bir arada değerlendirildiğinde ise şu sonuçların ortaya çıktığı gözlemlenmektedir:

- $\quad$ Tablo: 7'deki tutum grubu bir arada değerlendirildiğinde yüksek gelire sahip olanların, diğer gelir gruplarına kıyasla alkollü içeceklerin sebebiyet verebileceği sosyal maliyetlerin (şiddet, intihar olayları, hastalık riski) azaltılmasına dönük yüksek vergileri daha az destekledikleri sonucuna ulaşılmaktadır.

- $\quad$ Tablo: 7, tüm tutum grubu içerisinde düşük gelire sahip olanların diğger gelir gruplarına nazaran alkole ilişkin sosyal maliyetlerin azaltılmasına yönelik yüksek vergileri daha fazla desteklediklerini göstermektedir.

- $\quad$ Tablo: 7, tüm tutum ifadeleri ve gelir grupları içerisinde en güçlü tutumsal eğilimin, düşük gelir gruplarının alkollü içeceklerden alınan vergilerin özel bir fonda toplanması ve bu fonların alkollü içki kullanımına ilişkin hastalıkların iyileştirilmesinde kullanılmak şartıyla yüksek vergi artışlarını desteklemelerinde açığa çıktığını ortaya koymaktadır.

Tablo: 7

Gelir Değişkeni ile Alkollü İçeceklere Salınan Vergilerin Sosyal Maliyeti Azaltıcı Etkilerine Yönelik Bilişsel Tutumlar Arasındaki İlişkinin Sonuçları

\begin{tabular}{|c|c|c|c|c|}
\hline BİLISSSEL TUTUMLAR & $\begin{array}{l}\text { Geliri } 1000 \\
\text { TL'den az } \\
\text { olanlar } \\
\text { (Düşük) }\end{array}$ & $\begin{array}{c}\text { Geliri } \\
\text { 1001TL- } \\
\text { 2000TL arası } \\
\text { olanlar } \\
\text { (Orta-altı) }\end{array}$ & $\begin{array}{c}\text { Geliri } \\
\text { 2001TL- } \\
\text { 4000TL arası } \\
\text { olanlar } \\
\text { (Orta-üstü) }\end{array}$ & $\begin{array}{l}\text { Geliri } \\
\text { 4001TL } \\
\text { üzeri olanlar } \\
\text { (Yüksek) }\end{array}$ \\
\hline $\begin{array}{l}\text { Ĕger Alkollü İçeceklerden Alınan Vergiler, } \\
\text { Özel Bir Hesapta Toplanıp Alkol Kullanımına } \\
\text { İlişkin Hastalıkların İyileștirilmesinde } \\
\text { Kullanılacaksa Yüksek Vergi Artışlarını Kabul } \\
\text { Edebilirim }\end{array}$ & 397,41 & 365,06 & 329,72 & 342,37 \\
\hline $\begin{array}{c}\text { Alkollü İçeceklerin Tüketimi Üzerine Konulan } \\
\text { Yüksek Vergilerin Hastalık Riskini } \\
\text { Azaltacağına İnanıyorum. }\end{array}$ & 371,3 & 377,97 & 344,3 & 293,24 \\
\hline $\begin{array}{l}\text { Alkollü İçecek Tüketiminin Yüksek Vergilerle } \\
\text { Azalacağını Düşünüyorum }\end{array}$ & 375,79 & 385,13 & 328,04 & 276,51 \\
\hline $\begin{array}{c}\text { Aşırı Alkol Tüketimi Topluma Önemli } \\
\text { Maliyetler Yüklediği İçin Yüksek Oranlı Alkol } \\
\text { Vergilerini Destekliyorum }\end{array}$ & 389,26 & 375,1 & 332,15 & 286,28 \\
\hline $\begin{array}{l}\text { Alkollü İçeceklere Yüklenilen Yüksek Oranlı } \\
\text { Vergilerin Şiddet Ve İntihar Olaylarını } \\
\text { Azaltacağına İnanıyorum }\end{array}$ & 385,99 & 370,72 & 339,84 & 306,99 \\
\hline
\end{tabular}

Tablo: 8, alkollü içeceklerin üzerine salınan vergilerin medeni hal bağımsız değişkeni göz önünde bulundurularak nasıl bir tutumsal eğilim açığa çıkarttığını bir arada 
göstermektedir. Tablo: 8'deki veriler, Kruskal-Wallis U testi sonuçlarından elde edilen sıra ortalamalarını ifade etmektedir. Tablo: 8'deki verilere ilişkin tüm Kruskal-Wallis P değerleri, istatistiksel açıdan anlamlılık içermektedir (Ek: 1). Bu test analizleri bir arada değerlendirildiğinde şu sonuçların ortaya çıktığı görülmektedir:

- $\quad$ Tablo: 8'deki tutum ifadeleri bir arada değerlendirildiğinde dul ve bekârlara kıyasla evlilerin alkollü içeceklerin sebebiyet verebileceği sosyal maliyetlerin (şiddet, intihar olayları, hastalık riski) azaltılmasına dönük yüksek vergileri daha fazla destekledikleri görülmektedir.

- Tablo: 8'deki tüm tutum ifadeleri kapsamında, evli ve dullara nazaran bekârların sosyal maliyetlerin azaltılmasına yönelik yüksek vergiler konusunda daha zayıf tutuma sahip oldukları gözlemlenmektedir.

- Tablo: 8'e göre tüm tutum ifadeleri ve gelir grupları içerisinde en güçlü tutumsal eğilim ise, bekâr ve dullara kıyasla evlilerin alkollü içecekler üzerine salınan yüksek vergilerin hastalık riskini azaltacağına ilişkin tutumlarında görülmektedir.

Tablo: 8

Medeni Hal Değişkeni ile Alkollü İçeceklere Salınan Vergilerin Sosyal Maliyeti Azaltıcı Etkilerine Yönelik Bilişsel Tutumlar Arasındaki İlişkinin Sonuçları

\begin{tabular}{|l|c|c|c|}
\hline \multicolumn{1}{|c|}{ BİLIŞSEL TUTUMLAR } & EVLI & BEKÂR & DUL \\
\hline $\begin{array}{l}\text { Alkollü İ̧eceklerin Tüketimi Üzerine Konulan Yüksek Vergilerin Hastalık Riskini } \\
\text { Azaltacağına İnanıyorum. }\end{array}$ & 537,5 & 457,88 & 484,87 \\
\hline Alkollü İecek Tüketiminin Yüksek Vergilerle Azalacağını Düşünüyorum & 531,72 & 462,84 & 524,74 \\
\hline $\begin{array}{l}\text { Aşııı Alkol Tüketimi Topluma Önemli Maliyetler Yüklediği İçin Yüksek Oranlı } \\
\text { Alkol Vergilerini Destekliyorum }\end{array}$ & 533,12 & 461,3 & 517,12 \\
\hline $\begin{array}{l}\text { Eğer Alkollü İçeceklerden Alınan Vergiler, Özel Bir Hesapta Toplanıp Alkol } \\
\text { Kullanımına İlişkin Hastalıkların İyileştirilmesinde Kullanılacaksa Yüksek Vergi } \\
\text { Artışlarını Kabul Edebilirim }\end{array}$ & 531,42 & 468,93 & 491,28 \\
\hline $\begin{array}{l}\text { Alkollü İceceklere Yüklenilen Yüksek Oranlı Vergilerin Şiddet Ve İntihar } \\
\text { Olaylarını Azaltacağına İnanıyorum }\end{array}$ & 528,95 & 472,34 & 500,4 \\
\hline
\end{tabular}

Tablo: 9, alkollü içeceklerin üzerine salınan vergilerin eğitim bağımsız değişkeni göz önünde bulundurularak nasıl bir tutumsal eğilim açığa çıkarttığını topluca göstermektedir. Tablodaki veriler, Kruskal-Wallis U testi sonuçlarından elde edilen sıra ortalamalarını ifade etmektedir. Tablo: 9'daki verilere ilişkin tüm Kruskal-Wallis P değerleri, istatistiksel açıdan anlamlılık içermektedir (Ek: 1). Bu test analizleri bir arada değerlendirildiğinde şu sonuçların ortaya çıktığı gözlemlenmektedir:

- Tablo: 9'a ilişkin tutum ifadeleri bir arada değerlendirildiğinde, ilkokul mezunlarının diğer mezun gruplarına kıyasla alkollü içeceklerin sebebiyet verebileceği sosyal maliyetlerin (şiddet, intihar olayları, hastalık riski) 
azaltılmasına dönük yüksek vergileri daha fazla destekledikleri görülmektedir.

- Tablo: 9'a göre tüm tutum ifadeleri kapsamında diğer mezun gruplarına nazaran üniversite mezunları, alkollü içeceklere ilişkin sosyal maliyetlerin azaltılmasına yönelik yüksek vergiler konusunda daha zayıf tutumsal eğilim ortaya koymaktadırlar.

- $\quad$ Tablo: 9'a göre tüm tutum ifadeleri ve farklı eğitim seviyelerinde açığa çıkan en güçlü tutumsal eğilim, ilkokul mezunlarının alkollü içecekler üzerine salınan yüksek vergilerin hastalık riskini azaltacağına ilişkin tutumlarında görülmektedir.

Tablo: 9

\section{Eğitim Değişkeni İle Alkollü İçeceklere Salınan Vergilerin Sosyal Maliyeti Azaltıcı Etkilerine Yönelik Bilişsel Tutumlar Arasındaki İlişkinin Sonuçları}

\begin{tabular}{|l|c|c|c|c|}
\hline \multicolumn{1}{|c|}{ BíLişSEL TUTUMLAR } & $\begin{array}{c}\text { ILKOKUL } \\
\text { MEZUNU }\end{array}$ & $\begin{array}{c}\text { ORTAOKUL } \\
\text { MEZUNU }\end{array}$ & $\begin{array}{c}\text { LiSE } \\
\text { MEZUNU }\end{array}$ & $\begin{array}{c}\text { ÜNIVERSITE } \\
\text { MEZUNU }\end{array}$ \\
\hline $\begin{array}{l}\text { Alkollü İçeceklerin Tüketimi Üzerine } \\
\text { Konulan Yüksek Vergilerin Hastalık Riskini } \\
\text { Azaltacağına İnanıyorum }\end{array}$ & 546,63 & 487,29 & 438,4 & 432,16 \\
\hline $\begin{array}{l}\text { Alkollü İcecek Tüketiminin Yüksek } \\
\text { Vergilerle Azalacağını Düşünüyorum }\end{array}$ & 524,46 & 516,22 & 442,95 & 439,26 \\
\hline $\begin{array}{l}\text { Aşıı Alkol Tüketimi Topluma Önemli } \\
\text { Maliyetler Yüklediği İçin Yüksek Oranlı } \\
\text { Alkol Vergilerini Destekliyorum }\end{array}$ & 533,02 & 512,65 & 447,44 & 416,58 \\
\hline $\begin{array}{l}\text { Eğer Alkollü İeceklerden Alınan Vergiler, } \\
\text { Özel Bir Hesapta Toplanıp Alkol Kullanımına } \\
\text { İlişkin Hastalıkların İyileștirilmesinde } \\
\text { Kullanılacaksa Yüksek Vergi Artışlarını } \\
\text { Kabul Edebilirim }\end{array}$ & 518,69 & 481,84 & 457,5 & 450,9 \\
\hline $\begin{array}{l}\text { Alkollü İçeceklere Yüklenilen Yüksek Oranlı } \\
\text { Vergilerin Şiddet Ve İntihar Olaylarını } \\
\text { Azaltacağına İnanıyorum }\end{array}$ & 540,19 & 517,57 & 426,7 & 441,7 \\
\hline
\end{tabular}

\section{Sonuç}

Özel tüketim vergileri kapsamında ele alınan alkollü içecek vergilerinin sosyal maliyetleri azaltıcı etkileri medeni hal, gelir, ve eğitim bağımsız değişkeni çerçevesinde şu neticeleri açı̆̆a çıkartmaktadır:

Evliler, dul ve bekârlara kıyasla alkollü içecek vergilerinin içki tüketimine ilişkin sosyal maliyetleri azaltıcı etkilerini daha çok desteklemektedirler. Bu nitelikteki tutumlara yönelik olarak tüm medeni hal grupları içerisinde en zayıf tutumsal eğilimi bekârlar sergilemektedir. 
Gelir düzeyi 1000TL'den az düşük gelir grubu, diğer gelir gruplarına nazaran, alkollü içecek vergilerinin sosyal maliyetleri azaltıcı etkisini daha çok desteklemektedir. Tüm gelir grupları içerisinde alkollü içecek vergilerinin sosyal maliyetleri düşürebileceğini en az gelir düzeyi 4000TL'nin üzerinde olan gelir grupları düşünmektedir. Aynı zamanda bu değişkene ilişkin neticeler, gelir düzeyi ile alkol vergilemesinin sosyal maliyetleri azaltıcı etkilerine yönelik tutumlar arasında ters oranlı bir ilişkiyi de göstermektedir.

İlkokul mezunları, diğer mezun kategorilerine nazaran, alkollü içecek vergilerinin toplumsal maliyetleri hafifletebileceğini daha fazla düşünmektedirler. Tüm eğitim kategorileri içerisinde, alkollü içecek vergilerinin toplumsal maliyetleri azaltabileceğini en az üniversite mezunları düşünmektedirler. Aynı zamanda bu değişkene yönelik neticeler, alkollü içecek vergilerinin sosyal maliyetleri azaltıcı etkisi ile eğitim düzeyi arasında ters oranlı bir ilişkinin olduğunu da göstermektedir.

\section{Kaynakça}

Badenes-Pla, N. \& A.M. Jones (2003), "Addictive Goods and Taxes: A Survey From An Economic Perspective", Revista De Economia Publica, 167:4, 123-153.

Durrance, C.P. \& S. Golden \& K. Perreira \& P. Cook (2011), "Taxing Sin and Saving Lives: Can Alcohol Taxation Reduce Female Homicides?”, Soscial Science \& Medicine, 73, 169176.

Gabe, T. (2008), "Fiscal and Economic Impact of Beverage Excise Taxes Imposed By Maine Public Law 629”, 〈http://www.umaine.edu/soe/files/2009/06/bevtaxreport.pdf>, 13.01.2015.

Güler, F. (2008), Ístatistik Metodları ve Uygulamaları, Beta Yayınları, 2. Basım.

Heien, D.M. (1995), “Are Higher Alcohol Taxes Justified?”, Cato Journal, Vol:15, 243-257.

Lorenzi, P. (2004), "Sin Taxes", Society, 41:3, 59-65.

Nordblom, K. (2006), "The Complex Attitude to Alchohol Taxation", <https://gupea.ub.gu.se/bitstream/2077/2713/1/gunwpe0207.pdf>, 13.01.2015.

Sexton, R. (2013), Exploring Economics, South-Western, Cengage Learning.

Smith, S. (2005), "Economics Issues in Alcohol Taxation", in: Theory and Practice of Excise Taxation: Smoking, Drinking, Gambling, Polluting, and Driving, Editor: Sijbren Cnossen, Oxford University Press.

Son, C.H. \& K. Topyan (2011), "The Effect of Alcoholic Beverage Excise Tax on Alcohol Attributable Injury Mortalities", The European Journal of Health Economics, Volume 12, Issue 2, 103-113. 


\section{EK: 1}

Tablo: 10

"Eğer Alkollü İçeceklerden Alınan Vergiler, Özel Bir Hesapta Toplanıp Alkol Kullanımına İlişkin Hastalıkların İyileştirilmesinde Kullanılacaksa Yüksek Vergi Artışlarını Kabul Edebilirim” Bilişsel Tutumuna İlişskin Sıkık Analizi

\begin{tabular}{|c|c|c|c|}
\hline $\begin{array}{c}\text { Eğer Alkollü İçeceklerden Alınan Vergiler, Özel Bir Hesapta Toplanıp Alkol Kullanımına İlişkin Hastalıkların } \\
\text { İyileştirilmesinde Kullanılacaksa Yüksek Vergi Artışlarını Kabul Edebilirim }\end{array}$ & Siklık & Yüzde & $\begin{array}{l}\text { Geçerli } \\
\text { Yüzde }\end{array}$ \\
\hline Kesinlikle Katılmiyorum & 79 & 7,8 & 7,8 \\
\hline Kat1lmiyorum & 178 & 17,5 & 17,5 \\
\hline Ne Katıliyorum Ne De Katılmıyorum & 141 & 13,9 & 13,9 \\
\hline Katıliyorum & 478 & 47,0 & 47,0 \\
\hline Kesinlikle Katıliyorum & 142 & 13,9 & 13,9 \\
\hline Toplam & 1018 & 100,0 & 100,0 \\
\hline
\end{tabular}

Tablo: 11

“Alkollü İçeceklerin Tüketimi Üzerine Konulan Yüksek Vergilerin Hastalık Riskini Azaltacağına İnanıyorum” Bilişsel Tutumuna İlişkin Sıklık Analizi

\begin{tabular}{|c|c|c|c|}
\hline Alkollü İçeceklerin Tüketimi Üzerine Konulan Yüksek Vergilerin Hastalık Riskini Azaltacağına İnanıyorum & Siklık & Yüzde & Geçerli Yüzde \\
\hline Kesinlikle Katılmiyorum & 158 & 15,5 & 15,5 \\
\hline Katılmiyorum & 286 & 28,1 & 28,1 \\
\hline Ne Katıliyorum Ne De Katılmıyorum & 63 & 6,2 & 6,2 \\
\hline Katıliyorum & 432 & 42,4 & 42,4 \\
\hline Kesinlikle Katılıyorum & 79 & 7,8 & 7,8 \\
\hline TOPLAM & 1018 & 100,0 & 100,0 \\
\hline
\end{tabular}

Tablo: 12

“Alkollü İçecek Tüketiminin Yüksek Vergilerle Azalacağını Düşünüyorum” Bilişsel Tutumuna İlişkin Sıklık Analizi

\begin{tabular}{|c|c|c|c|}
\hline Alkollü İçecek Tüketiminin Yüksek Vergilerle Azalacağını Düşünüyorum & Siklik & Yüzde & Geçerli Yüzde \\
\hline Kesinlikle Katılmiyorum & 148 & 14,5 & 14,5 \\
\hline Katılmiyorum & 280 & 27,5 & 27,5 \\
\hline Ne Katıliyorum Ne De Katılmıyorum & 83 & 8,2 & 8,2 \\
\hline Katıliyorum & 414 & 40,7 & 40,7 \\
\hline Kesinlikle Katıliyorum & 93 & 9,1 & 9,1 \\
\hline TOPLAM & 1018 & 100,0 & 100,0 \\
\hline
\end{tabular}

Tablo: 13

“Aşırı Alkol Tüketimi Topluma Önemli Maliyetler Yüklediği İçin Yüksek Oranlı Alkol Vergilerini Destekliyorum” Bilișsel Tutumuna İlişsin Sıklık Analizi

\begin{tabular}{|c|c|c|c|}
\hline Aşırı Alkol Tüketimi Topluma Önemli Maliyetler Yüklediği İçin Yüksek Oranlı Alkol Vergilerini Destekliyorum & S1klik & Yüzde & Geçerli Yüzde \\
\hline Kesinlikle Katılmiyorum & 137 & 13,5 & 13,5 \\
\hline Katılmiyorum & 265 & 26,0 & 26,0 \\
\hline Ne Katıliyorum Ne De Katılmiyorum & 114 & 11,2 & 11,2 \\
\hline Katiliyorum & 402 & 39,5 & 39,5 \\
\hline Kesinlikle Katıliyorum & 100 & 9,8 & 9,8 \\
\hline Toplam & 1018 & 100,0 & 100,0 \\
\hline
\end{tabular}


Tablo: 14

“Alkollü İçeceklere Yüklenilen Yüksek Oranlı Vergilerin Şiddet ve İntihar Olaylarını Azaltacağına İnanıyorum” Bilişsel Tutumuna İliş̧kin Sıklık Analizi

\begin{tabular}{|l|r|r|r|}
\hline Alkollü İceceklere Yüklenilen Yüksek Oranlı Vergilerin Şiddet ve İntihar Olaylarını Azaltacağına İnanıyorum & Sıklık & Yüzde & Geçerli Yüzde \\
\hline Kesinlikle Katılmıyorum & 169 & 16,6 & 16,6 \\
\hline Katılmıyorum & 294 & 28,9 & 28,9 \\
\hline Ne Katıllyorum Ne De Katılmıyorum & 112 & 11,0 & 11,0 \\
\hline Katılıyorum & 381 & 37,4 & 37,4 \\
\hline Kesinlikle Katıllyorum & 62 & 6,1 & 6,1 \\
\hline Toplam & 1018 & 100,0 & 100,0 \\
\hline
\end{tabular}

Tablo: 15

"Ĕger Alkollü İçeceklerden Alınan Vergiler, Özel Bir Hesapta Toplanıp Alkol Kullanımına İlişsin Hastalıkların İyileştirilmesinde Kullanılacaksa Yüksek Vergi Artışlarını Kabul Edebilirim” Bilişsel Tutumu İle Gelir Değişkeni Arasındaki Kruskal-Wallis H Anlamlı Fark Testi

\begin{tabular}{|c|c|c|c|}
\hline \multicolumn{2}{|l|}{ GELIR DÜZEYİ } & $\begin{array}{c}\text { Örnek } \\
\text { Kitle }\end{array}$ & $\begin{array}{c}\text { Sira } \\
\text { Ortalamas } 1\end{array}$ \\
\hline \multirow{5}{*}{$\begin{array}{l}\text { Eğer Alkollü İçeceklerden Alınan Vergiler, Özel Bir Hesapta Toplanıp } \\
\text { Alkol Kullanımına İlişkin Hastalıların Iyileştirilmesinde } \\
\text { Kullanılacaksa Yüksek Vergi Artışlarını Kabul Edebilirim }\end{array}$} & Geliri 1000 TL'den az olanlar (Düşük) & 179 & 397,41 \\
\hline & Geliri 1001TL-2000TL aras1 olanlar (Orta-alt1) & 347 & 365,06 \\
\hline & Geliri 2001TL-4000TL aras1 olanlar (Orta-üstü) & 158 & 329,72 \\
\hline & Geliri 4001TL üzeri olanlar (Yüksek) & 43 & 342,37 \\
\hline & Total & 727 & \\
\hline \multicolumn{4}{|l|}{ Kruskal-Wallis Anlamlılık P Değeri: ,016 } \\
\hline \multicolumn{3}{|c|}{$\mathrm{H}_{\mathrm{o}}$ : İlgili Tutum Değişkeni ile Gelir Bağımsız Değişkeni Arasında Anlamlı Fark Yoktur. } & RED \\
\hline \multicolumn{3}{|c|}{$\mathrm{H}_{1}$ : İlgili Tutum Değişkeni ile Gelir Bağımsız Değişkeni Arasında Anlamlı Fark Vardır. } & KABUL \\
\hline
\end{tabular}

Tablo: 16

"Alkollü İçeceklerin Tüketimi Üzerine Konulan Yüksek Vergilerin Hastalık Riskini Azaltacağına İnanıyorum” Bilişsel Tutumu ile Gelir Düzeyi Değişkeni Arasındaki Kruskal-Wallis H Anlamlı Fark Testi

\begin{tabular}{|c|c|c|c|}
\hline \multicolumn{2}{|c|}{ GELİR DÜZEYİ } & $\begin{array}{l}\text { Örnek } \\
\text { Kitle }\end{array}$ & $\begin{array}{c}\text { Sira } \\
\text { Ortalamas1 } \\
\end{array}$ \\
\hline \multirow{5}{*}{$\begin{array}{l}\text { Alkollü İçeceklerin Tüketimi Üzerine Konulan Yüksek Vergilerin } \\
\text { Hastalık Riskini Azaltacağına İnanıyorum }\end{array}$} & Geliri 1000 TL'den az olanlar (Düşük) & 179 & 371,30 \\
\hline & Geliri 1001TL-2000TL aras1 olanlar (Orta-alt1) & 347 & 377,97 \\
\hline & Geliri 2001TL-4000TL arası olanlar (Orta-üstü) & 158 & 344,30 \\
\hline & Geliri 4001TL üzeri olanlar (Yüksek) & 43 & 293,24 \\
\hline & Toplam & 727 & \\
\hline \multicolumn{4}{|c|}{ Kruskal-Wallis Anlamlılık P Değeri: ,031 } \\
\hline \multicolumn{3}{|c|}{$\mathrm{H}_{\mathrm{o}}$ : İlgili Tutum Değişkeni ile Gelir Bağımsız Değişkeni Arasında Anlamlı Fark Yoktur. } & RED \\
\hline \multicolumn{3}{|c|}{$\mathrm{H}_{1}$ : İlgili Tutum Değişkeni ile Gelir Bağımsız Değişkeni Arasında Anlamlı Fark Vardır. } & KABUL \\
\hline
\end{tabular}


Tablo: 17

“Alkollü İçecek Tüketiminin Yüksek Vergilerle Azalacağını Düşünüyorum” Bilișsel Tutumu ile Gelir Değişkeni Arasındaki Kruskal-Wallis H Anlamlı Fark Testi

\begin{tabular}{|c|c|c|c|}
\hline \multicolumn{2}{|c|}{ GELİR DÜZEYİ } & Örnek Kitle & Sira Ortalaması \\
\hline \multirow{5}{*}{$\begin{array}{l}\text { Alkollü İçecek Tüketiminin Yüksek Vergilerle } \\
\text { Azalacağını Düşünüyorum }\end{array}$} & Geliri 1000 TL'den az olanlar (Düşük) & 179 & 375,79 \\
\hline & Geliri 1001TL-2000TL arası olanlar (Orta-alt1) & 347 & 385,13 \\
\hline & Geliri 2001TL-4000TL aras1 olanlar (Orta-üstü) & 158 & 328,04 \\
\hline & Geliri 4001TL üzeri olanlar (Yüksek) & 43 & 276,51 \\
\hline & Toplam & 727 & \\
\hline \multicolumn{4}{|l|}{ Kruskal-Wallis Anlamlılık P Değeri: ,001 } \\
\hline \multicolumn{3}{|c|}{$\mathrm{H}_{\mathrm{o}}$ : İlgili Tutum Değişkeni ile Gelir Bağımsız Değişkeni Arasında Anlamlı Fark Yoktur. } & RED \\
\hline \multicolumn{3}{|c|}{$\mathrm{H}_{1}$ : İlgili Tutum Değișkeni ile Gelir Bağımsız Değișkeni Arasında Anlamlı Fark Vardır. } & KABUL \\
\hline
\end{tabular}

Tablo: 18

“Aşırı Alkol Tüketimi Topluma Önemli Maliyetler Yüklediği İçin Yüksek Oranlı Alkol Vergilerini Destekliyorum” Bilişsel Tutumu İle Gelir Değişseni Arasındaki Kruskal-Wallis H Anlamlı Fark Testi

\begin{tabular}{|c|c|c|c|}
\hline \multicolumn{2}{|c|}{ GELIR DÜZEYİ } & $\begin{array}{c}\text { Örnek } \\
\text { Kitle }\end{array}$ & $\begin{array}{c}\text { Sira } \\
\text { Ortalamas }\end{array}$ \\
\hline \multirow{5}{*}{$\begin{array}{l}\text { Aşırı Alkol Tüketimi Topluma Önemli Maliyetler Yüklediği İçin } \\
\text { Yüksek Oranlı Alkol Vergilerini Destekliyorum }\end{array}$} & Geliri 1000 TL'den az olanlar (Düşük) & 179 & 389,26 \\
\hline & Geliri 1001TL-2000TL aras1 olanlar (Orta-alt1) & 347 & 375,10 \\
\hline & Geliri 2001TL-4000TL aras1 olanlar (Orta-üstü) & 158 & 332,15 \\
\hline & Geliri 4001TL üzeri olanlar (Yüksek) & 43 & 286,28 \\
\hline & Total & 727 & \\
\hline \multicolumn{4}{|c|}{ Kruskal-Wallis Anlamlılık P Değeri: ,003 } \\
\hline \multicolumn{3}{|c|}{$\mathrm{H}_{\mathrm{o}}$ : İlgili Tutum Değişkeni ile Gelir Bağımsız Değişkeni Arasında Anlamlı Fark Yoktur. } & RED \\
\hline \multicolumn{3}{|c|}{$\mathrm{H}_{1}$ : İlgili Tutum Değişkeni ile Gelir Bağımsız Değişkeni Arasında Anlamlı Fark Vardır. } & KABUL \\
\hline
\end{tabular}

Tablo: 19

"Alkollü İçeceklere Yüklenilen Yüksek Oranlı Vergilerin Şiddet ve İntihar Olaylarını Azaltacağına İnanıyorum” Bilişsel Tutumu İle Gelir Değişkeni Arasındaki KruskalWallis H Anlamlı Fark Testi

\begin{tabular}{|c|c|c|c|}
\hline \multicolumn{2}{|l|}{ GELİR DÜZEYİ } & $\begin{array}{c}\text { Örnek } \\
\text { Kitle }\end{array}$ & $\begin{array}{c}\text { Sira } \\
\text { Ortalamas } 1 \\
\end{array}$ \\
\hline \multirow{5}{*}{$\begin{array}{l}\text { Alkollü İçeceklere Yüklenilen Yüksek Oranlı Vergilerin Şiddet ve } \\
\text { İntihar Olaylarını Azaltacağına İnanıyorum }\end{array}$} & Geliri 1000 TL'den az olanlar (Düşük) & 179 & 385,99 \\
\hline & Geliri 1001TL-2000TL aras1 olanlar (Orta-alt1) & 347 & 370,72 \\
\hline & Geliri 2001TL-4000TL arası olanlar (Orta-üstü) & 158 & 339,84 \\
\hline & Geliri 4001TL üzeri olanlar (Yüksek) & 43 & 306,99 \\
\hline & Toplam & 727 & \\
\hline \multicolumn{4}{|c|}{ Kruskal-Wallis Anlamlılık P Değeri: ,042 } \\
\hline \multicolumn{3}{|c|}{$\mathrm{H}_{\mathrm{o}}$ : İlgili Tutum Değişkeni ile Gelir Bağımsız Değişkeni Arasında Anlamlı Fark Yoktur. } & RED \\
\hline \multicolumn{3}{|c|}{$\mathrm{H}_{1}$ : İlgili Tutum Değişkeni ile Gelir Bağımsız Değişkeni Arasında Anlamlı Fark Vardır. } & KABUL \\
\hline
\end{tabular}


Tablo: 20

“Alkollü İçeceklerin Tüketimi Üzerine Konulan Yüksek Vergilerin Hastalık Riskini Azaltacağına İnanıyorum” Bilişsel Tutumu ile Medeni Hal Değişkeni Arasındaki Kruskal-Wallis H Anlamlı Fark Testi

\begin{tabular}{|c|c|c|c|}
\hline \multicolumn{2}{|l|}{ MEDENİ HAL } & $\begin{array}{c}\text { Örnek } \\
\text { Kitle }\end{array}$ & $\begin{array}{c}\text { Sira } \\
\text { Ortalamas1 }\end{array}$ \\
\hline \multirow{4}{*}{$\begin{array}{l}\text { Alkollü İçeceklerin Tüketimi Üzerine Konulan Yüksek Vergilerin Hastalık Riskini Azaltacağına } \\
\text { İnanıyorum }\end{array}$} & Evli & 642 & 537,50 \\
\hline & Bekâr & 323 & 457,88 \\
\hline & Dul & 53 & 484,87 \\
\hline & Total & 1018 & \\
\hline \multicolumn{4}{|l|}{ Kruskal-Wallis Anlamlılık P Değeri: ,000 } \\
\hline \multicolumn{3}{|l|}{$\mathrm{H}_{\mathrm{o}}$ : İlgili Tutum Değişkeni ile Medeni Hal Bağımsız Değişkeni Arasında Anlamlı Fark Yoktur. } & RED \\
\hline \multicolumn{3}{|l|}{ H $\mathrm{H}_{1}$ : İlgili Tutum Değişkeni ile Medeni Hal Bağımsız Değişkeni Arasında Anlamlı Fark Vardır. } & KABUL \\
\hline
\end{tabular}

Tablo: 21

“Alkollü İçecek Tüketiminin Yüksek Vergilerle Azalacağını Düşünüyorum” Bilişsel Tutumu ile Medeni Hal Bağımsız Değişkeni Arasındaki Kruskal-Wallis H Anlamlı Fark Testi

\begin{tabular}{|c|c|c|c|}
\hline \multicolumn{2}{|l|}{ MEDENI HAL } & Örnek Kitle & Sira Ortalamas1 \\
\hline \multirow{4}{*}{ Alkollü İçecek Tüketiminin Yüksek Vergilerle Azalacağını Düşünüyorum } & Evli & 642 & 531,72 \\
\hline & Bekâr & 323 & 462,84 \\
\hline & Dul & 53 & 524,74 \\
\hline & Total & 1018 & \\
\hline \multicolumn{4}{|l|}{ Kruskal-Wallis Anlamlılık P Değeri: ,001 } \\
\hline \multirow{2}{*}{\multicolumn{3}{|c|}{$\begin{array}{l}H_{0} \text { : İlgili Tutum Değğşkeni ile Medeni Hal Bağımsız Değişkeni Arasında Anlamlı Fark Yoktur. } \\
\text {H}_{1} \text { : İlgili Tutum Değișkeni ile Medeni Hal Bağımsız Değişkeni Arasında Anlamlı Fark Vardır. }\end{array}$}} & RED \\
\hline & & & KABUL \\
\hline
\end{tabular}

Tablo: 22

“Aşırı Alkol Tüketimi Topluma Önemli Maliyetler Yüklediği İçin Yüksek Oranlı Alkol Vergilerini Destekliyorum " Bilişsel Tutumu ile Medeni Hal Bağımsız Değişkeni Arasındaki Kruskal-Wallis H Anlamlı Fark Testi

\begin{tabular}{|c|c|c|c|}
\hline \multicolumn{2}{|l|}{ MEDENİ HAL } & $\begin{array}{c}\text { Örnek } \\
\text { Kitle }\end{array}$ & $\begin{array}{c}\text { Sira } \\
\text { Ortalamas1 } \\
\end{array}$ \\
\hline \multirow{4}{*}{$\begin{array}{l}\text { Aşırı Alkol Tüketimi Topluma Önemli Maliyetler Yüklediği İçin Yüksek Oranlı Alkol Vergilerini } \\
\text { Destekliyorum }\end{array}$} & Evli & 642 & 533,12 \\
\hline & Bekâr & 323 & 461,30 \\
\hline & Dul & 53 & 517,12 \\
\hline & Total & 1018 & \\
\hline \multicolumn{4}{|l|}{ Kruskal-Wallis Anlamlılık P Değeri: ,001 } \\
\hline \multicolumn{3}{|l|}{$\mathrm{H}_{\mathrm{o}}$ : İlgili Tutum Değişkeni ile Medeni Hal Bağımsız Değişkeni Arasında Anlamlı Fark Yoktur. } & RED \\
\hline \multicolumn{3}{|l|}{$\mathrm{H}_{1}$ : İlgili Tutum Değişkeni ile Medeni Hal Bağımsız Değişkeni Arasında Anlamlı Fark Vardır. } & KABUL \\
\hline
\end{tabular}


Tablo: 23

"Eğer Alkollü İçeceklerden Alınan Vergiler, Özel Bir Hesapta Toplanıp Alkol Kullanımına İlişkin Hastalıkların İyileștirilmesinde Kullanılacaksa Yüksek Vergi Artışlarını Kabul Edebilirim” Bilişsel Tutumu İle Medeni Hal Bağımsız Değişkeni Arasındaki Kruskal-Wallis H Anlamlı Fark Testi

\begin{tabular}{|l|l|l|}
\hline \multicolumn{2}{|c|}{ MEDENİ HAL } & \multicolumn{2}{|c}{$\begin{array}{c}\text { Örnek } \\
\text { Kitle }\end{array}$} \\
Ortalaması
\end{tabular}

Tablo: 24

“Alkollü İçeceklere Yüklenilen Yüksek Oranlı Vergilerin Şiddet ve İntihar Olaylarını Azaltacağına İnanıyorum” Bilişsel Tutumu ile Medeni Hal Değişkeni Arasındaki Kruskal-Wallis H Anlamlı Fark Testi

\begin{tabular}{|c|c|c|c|}
\hline \multicolumn{2}{|l|}{ MEDENI HAL } & $\begin{array}{l}\text { Örnek } \\
\text { Kitle }\end{array}$ & $\begin{array}{c}\text { Sira } \\
\text { Ortalamas1 }\end{array}$ \\
\hline \multirow{4}{*}{$\begin{array}{l}\text { Alkollü İçeceklere Yüklenilen Yüksek Oranlı Vergilerin Şiddet ve İntihar Olaylarını Azaltacağına } \\
\text { İnanıyorum }\end{array}$} & Evli & 642 & 528,95 \\
\hline & Bekâr & 323 & 472,34 \\
\hline & Dul & 53 & 500,40 \\
\hline & Total & 1018 & \\
\hline \multicolumn{4}{|l|}{ Kruskal-Wallis Anlamlılık P Değeri: ,013 } \\
\hline \multicolumn{3}{|l|}{$\mathrm{H}_{\mathrm{o}}$ : İlgili Tutum Değişkeni ile Medeni Hal Bağımsız Değişkeni Arasında Anlamlı Fark Yoktur. } & RED \\
\hline $\mathrm{H}_{1}$ : İlgili Tutum Değişkeni ile Medeni Hal Bağımsız Değişkeni Arasında Anlamlı Fark Vardır. & & & KABUL \\
\hline
\end{tabular}

Tablo: 25

“Alkollü İçeceklerin Tüketimi Üzerine Konulan Yüksek Vergilerin Hastalık Riskini Azaltacağına İnanıyorum” Bilişsel Tutumu ile Eğitim Değişkeni Arasındaki KruskalWallis H Testi

\begin{tabular}{|c|c|c|c|}
\hline \multicolumn{2}{|l|}{ EĞİTİM DÜZEYİ } & $\begin{array}{c}\text { Örnek } \\
\text { Kitle }\end{array}$ & $\begin{array}{c}\text { Sira } \\
\text { Ortalamas1 }\end{array}$ \\
\hline \multirow{5}{*}{$\begin{array}{l}\text { Alkollü İçeceklerin Tüketimi Üzerine Konulan Yüksek Vergilerin Hastalık Riskini Azaltacağına } \\
\text { İnanıyorum }\end{array}$} & İlkokul Mezunu & 312 & 546,63 \\
\hline & Ortaokul Mezunu & 146 & 487,29 \\
\hline & Lise Mezunu & 339 & 438,40 \\
\hline & Üniversite Mezunu & 162 & 432,16 \\
\hline & Toplam & 959 & \\
\hline \multicolumn{4}{|l|}{ Kruskal-Wallis Anlamlılık P Değeri: ,000 } \\
\hline \multirow{2}{*}{\multicolumn{3}{|c|}{$\mathrm{H}_{\mathrm{o}}$ : İlgili Tutum Değişkeni ile Eğitim Bağımsız Değişkeni Arasında Anlamlı Fark Yoktur. }} & RED \\
\hline \multicolumn{2}{|l|}{$\mathrm{H}_{1}$ : İlgili Tutum Değişkeni ile Eğitim Bağımsız Değişkeni Arasında Anlamlı Fark Vardır. } & & KABUL \\
\hline
\end{tabular}


Tablo: 26

“Alkollü İçecek Tüketiminin Yüksek Vergilerle Azalacağını Düşünüyorum” Bilişsel Tutumu ile Eğitim Değişkeni Arasındaki Kruskal-Wallis H Testi

\begin{tabular}{|c|c|c|c|}
\hline \multicolumn{2}{|l|}{ EĞİTİM DÜZEYİ } & Örnek Kitle & Sira Ortalamas 1 \\
\hline \multirow{5}{*}{ Alkollü İçecek Tüketiminin Yüksek Vergilerle Azalacağını Düşünüyorum } & İlkokul Mezunu & 312 & 524,46 \\
\hline & Ortaokul Mezunu & 146 & 516,22 \\
\hline & Lise Mezunu & 339 & 442,95 \\
\hline & Üniversite Mezunu & 162 & 439,26 \\
\hline & Toplam & 959 & \\
\hline \multicolumn{4}{|l|}{ Kruskal-Wallis Anlamlılık P Değeri: ,000 } \\
\hline \multicolumn{3}{|c|}{$\mathrm{H}_{\mathrm{o}}$ : İlgili Tutum Değişkeni ile Eğitim Bağımsız Değişkeni Arasında Anlamlı Fark Yoktur. } & RED \\
\hline \multicolumn{3}{|c|}{$\mathrm{H}_{1}$ : İlgili Tutum Değișkeni ile Eğitim Bağımsız Değișkeni Arasında Anlamlı Fark Vardır. } & KABUL \\
\hline
\end{tabular}

Tablo: 27

"Aşırı Alkol Tüketimi Topluma Önemli Maliyetler Yüklediği İçin Yüksek Oranlı Alkol Vergilerini Destekliyorum” Bilişsel Tutumu ile Eğitim Değişkeni Arasındaki Kruskal-Wallis H Testi

\begin{tabular}{|c|c|c|c|}
\hline \multicolumn{2}{|l|}{ EĞİTIM DÜZEYİ } & $\begin{array}{l}\text { Örnek } \\
\text { Kitle }\end{array}$ & $\begin{array}{c}\text { Sira } \\
\text { Ortalamas }\end{array}$ \\
\hline \multirow{5}{*}{$\begin{array}{l}\text { Aşırı Alkol Tüketimi Topluma Önemli Maliyetler Yüklediği İçin Yüksek Oranlı Alkol } \\
\text { Vergilerini Destekliyorum }\end{array}$} & İlkokul Mezunu & 312 & 533,02 \\
\hline & Ortaokul Mezunu & 146 & 512,65 \\
\hline & Lise Mezunu & 339 & 447,44 \\
\hline & Üniversite Mezunu & 162 & 416,58 \\
\hline & Toplam & 959 & \\
\hline \multicolumn{4}{|l|}{ Kruskal-Wallis Anlamlılık P Değeri: ,000 } \\
\hline \multirow{2}{*}{\multicolumn{3}{|c|}{$\begin{array}{l}\text { Ho: İlgili Tutum Değişkeni ile Eğitim Bağımsız Değişkeni Arasında Anlamlı Fark Yoktur. } \\
\mathrm{H}_{1} \text { : İlgili Tutum Değiskeni ile Eğitim Bă̆ımsız Değiskeni Arasında Anlamlı Fark Vardır. }\end{array}$}} & RED \\
\hline & & & KABUL \\
\hline
\end{tabular}

Tablo: 28

"Eğer Alkollü İçeceklerden Alınan Vergiler, Özel Bir Hesapta Toplanıp Alkol Kullanımına İlişkin Hastalıkların İyileştirilmesinde Kullanılacaksa Yüksek Vergi Artışlarını Kabul Edebilirim” Bilişsel Tutumu İle Eğitim Değişkeni Arasındaki Kruskal-Wallis H Testi

\begin{tabular}{|c|c|c|c|}
\hline \multicolumn{2}{|l|}{ EĞİTİM DÜZEYİ } & $\begin{array}{l}\text { Örnek } \\
\text { Kitle }\end{array}$ & $\begin{array}{c}\text { Sira } \\
\text { Ortalamas } 1\end{array}$ \\
\hline \multirow{5}{*}{$\begin{array}{l}\text { Eğer Alkollü İçeceklerden Alınan Vergiler, Özel Bir Hesapta Toplanıp Alkol Kullanımına İlişkin } \\
\text { Hastalıkların İyileştirilmesinde Kullanılacaksa Yüksek Vergi Artışlarını Kabul Edebilirim }\end{array}$} & İlkokul Mezunu & 312 & 518,69 \\
\hline & Ortaokul Mezunu & 146 & 481,84 \\
\hline & Lise Mezunu & 339 & 457,50 \\
\hline & Üniversite Mezunu & 162 & 450,90 \\
\hline & Toplam & 959 & \\
\hline \multicolumn{4}{|l|}{ Kruskal-Wallis Anlamlılık P Değeri: ,010 } \\
\hline \multicolumn{3}{|l|}{$\mathrm{H}_{\mathrm{o}}$ : İlgili Tutum Değişkeni ile Eğitim Bağımsız Değişkeni Arasında Anlamlı Fark Yoktur. } & RED \\
\hline \multicolumn{3}{|l|}{$\mathrm{H}_{1}$ : İlgili Tutum Değişkeni ile Eğitim Bağımsız Değişkeni Arasında Anlamlı Fark Vardır. } & KABUL \\
\hline
\end{tabular}


Tablo: 29

“Alkollü İçeceklere Yüklenilen Yüksek Oranlı Vergilerin Şiddet ve İntihar Olaylarını Azaltacağına İnanıyorum” Davranışsal Tutumu İle Eğitim Değişkeni Arasındaki Kruskal-Wallis H Testi

\begin{tabular}{|c|c|c|c|}
\hline \multicolumn{2}{|l|}{ EĞİTíM DÜZEYİ } & $\begin{array}{c}\text { Örnek } \\
\text { Kitle }\end{array}$ & $\begin{array}{c}\text { Sira } \\
\text { Ortalamasi }\end{array}$ \\
\hline \multirow{5}{*}{$\begin{array}{l}\text { Alkollü İçeceklere Yüklenilen Yüksek Oranlı Vergilerin Şiddet ve İntihar Olaylarını } \\
\text { Azaltacağına İnanıyorum }\end{array}$} & İlkokul Mezunu & 312 & 540,19 \\
\hline & Ortaokul Mezunu & 146 & 517,57 \\
\hline & \begin{tabular}{|l|l} 
Lise Mezunu \\
\end{tabular} & 339 & 426,73 \\
\hline & Üniversite Mezunu & 162 & 441,70 \\
\hline & \begin{tabular}{|l|} 
Toplam \\
\end{tabular} & 959 & \\
\hline \multicolumn{4}{|l|}{ Kruskal-Wallis Anlamlilık P Değeri: ,000 } \\
\hline \multicolumn{3}{|l|}{$\begin{array}{l}\mathrm{H}_{0} \text { : İlgili Tutum Değişkeni ile Eğitim Bağımsız Değişkeni Arasında Anlamlı Fark Yoktur. } \\
\mathrm{H}_{1} \text { : Illoili Tutum Deŏiskeni ile Eŏitim Bă̆msız Deơiskeni Arasında Anlamlı Fark Vardır }\end{array}$} & RED \\
\hline $\mathrm{H}_{1}$ : İlgili Tutum Değişkeni ile Eğitim Bağımsız Değişkeni Arasında Anlamlı Fark Vardır. & & & KABUL \\
\hline
\end{tabular}

